\title{
THE LITTLE BUTTYMEN IN THE FOREST OF DEAN, 1870-86*
}

On a superficial inspection, miners' unionism in the Forest of Dean between 1871 and 1886 does not appear to have been atypical of miners' unionism in general in Britain in that period: neither in the fluctuations in its strength nor in its policies. Like the unions in most other coal districts, that in Dean flourished in the economic boom of the early 1870 's, fell into weakness after 1875 and then revived in the early 1880's. In each of those phases the policies of the Dean miners were much like those of other miners. They demanded increases in wages, resisted reductions in wages, insisted upon the installation of weighing machines at pit bank, and sought to have winding hours reduced. Demands for the introduction of a sliding scale, to govern the movement of hewing rates in relation to coal prices, and for the establishment of conciliation and arbitration machinery, were common to many miners' unions at both local and national level. With those demands went the common rhetoric of the identity of interests of capital and labour. All this is the familiar content of that moderate, cautious, market-conscious approach to dealings with the masters which dominated miners' organisations for most of the second half of the century.

On closer examination, however, the union in the Forest of Dean is seen to have had a number of distinctive characteristics, which it is the purpose of this article to examine. Miners' unionism in Dean, it will be argued, should be understood in the context of the "little butty" system of work organisation. That system created divisions within the colliery workforce, which affected the behaviour and the policies of the union, its wage bargaining and its relations with the masters. Though little buttymen were to be found in a number of coalfields until the end of the century, no attempt has been made so far to assess their influence on miners' organisations. Though the evidence for the Forest is in many ways weak and unsatisfac-

* In the larger project on which this paper is based I had the help and advice of Professor R. Harrison and Dr A. Mason, of the Centre for the Study of Social History, and Dr F. Reid, of the History Department, at the University of Warwick. 
tory, enough has survived to suggest that a more extensive investigation of the buttymen is necessary.

The Forest of Dean lies in Western Gloucestershire, between the rivers Severn and Wye, hard up against the border between England and Wales. From perhaps before Roman times seams of coal had been mined beneath the Forest. The men who mined it did so within the terms of a peculiar set of local customs known as the "free miners' rights". ${ }^{1}$ The principal effect of those customs had been to limit the right to take minerals from the ground to natives of the Forest and to exclude "foreigners": people who had been born anywhere other than in the Forest. The customs survived, largely intact, until about 1800. Until then, the pits were small and worked cooperatively, without the aid of steam machinery, by the men who owned them. Markets were local and the transport system based on small donkey teams.

From about 1800 all that changed. Pressure for change came from those who wished to have the help of steam machinery in working deep coal. To buy the machines it was necessary to have capital, and to have capital it was necessary to bring foreigners into partnership with local men. Once that had been achieved, once the customary barriers against the foreigners had been broken down, the character of the industry altered. Since partnership ventures proved unsatisfactory, ownership of most of the mines passed quickly into the hands of a few foreign capitalists. The new men introduced steam pumping and winding machinery, drove their pits to previously inaccessible depths, and linked the Forest to a national transportation system through a grid of tramways and railways. New capital gave a strong impetus to the growth of coal mining in the first three quarters of the century. Between 1841 and 1871 the number of males employed in the industry increased from 1,544 to $3,375 .^{2}$ The annual output of coal grew by about 600 per cent, from 145,136 to 837,893 tons, in the same period. ${ }^{3}$

Most of the Forest's output now came from a small number of relatively large pits. Table 1 shows the pits in Dean in groups according to the size of their annual outputs, at five-year intervals from 1865 to 1885 . There were still many tiny pits whose annual output was less than 5,000 tons: in 1880, two thirds of the pits in Dean were in that category. Those were the levels

${ }^{1}$ See Ch. Fisher, "The Free Miners of the Forest of Dean", in: Independent Collier, ed. by R. Harrison (Hassocks, 1978).

2 Census of England and Wales, 6 June 1841, Public Record Office, HO 107/364-65; 2 April 1871, RG 10/2, 596-605, 686; 5, 296-300.

3 Dean Forest, Coal and Iron Mine Rentals, Public Record Office, LRRO 12/113-14. 


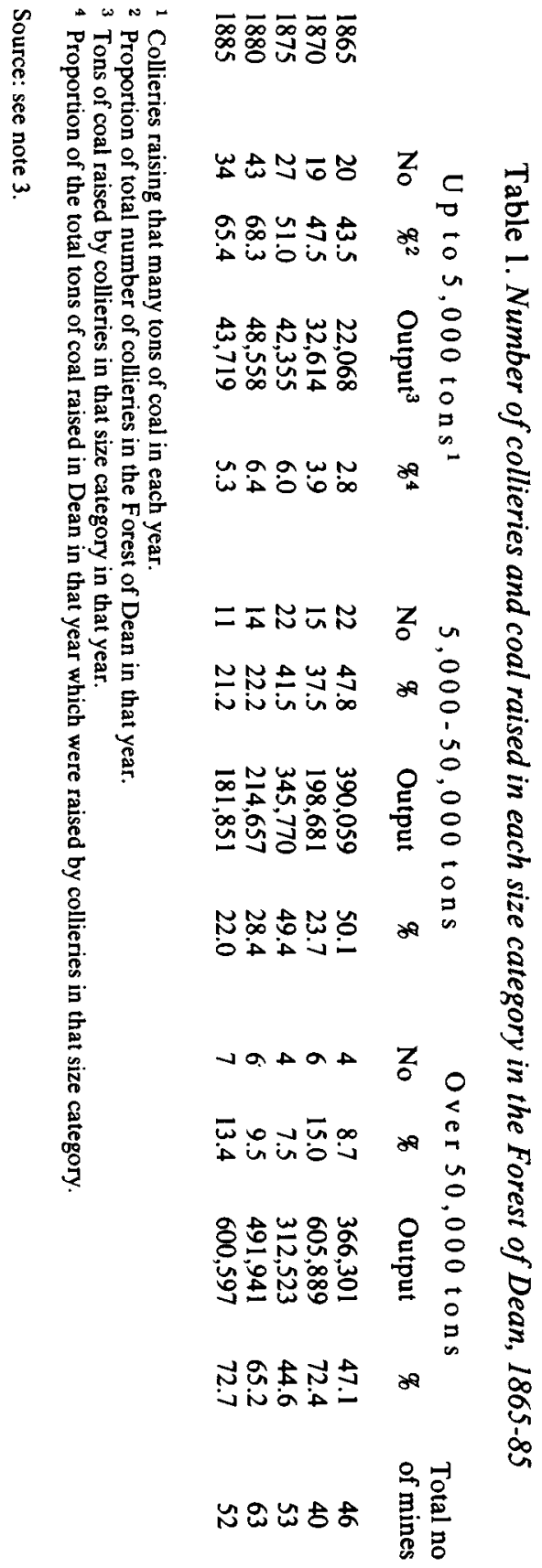


and shallow pits which the free miners still worked in the outcrops of the main seams, supplying the winter trade in household coal to the farmers in the surrounding countryside. But, in 1880 , those pits raised only 6.4 per cent of total output. Most of the coal raised came from those which produced more than 50,000 tons in each year. Half a dozen of them in 1880 , about one tenth of the total number of mines in Dean, accounted for about two thirds of output.

Work in the large pits, from the early 1820 's, came to be organised around contract miners, or buttymen. ${ }^{4}$ The masters employed some men on day wages, in order to maintain travelling and haulage roads in the pit, but most of those whose pay came directly from the master were contract men. A man and his mate (the butties) undertook to work a stall. ${ }^{5}$ That is, they agreed to hew the coal and load it into tubs, for which they received a stipulated rate per ton (the contract). The butties then employed men and boys at a fixed rate per day (the daymen) to help with the work. The butty paid his daymen rates which varied according to his assessment of their value as workmen. That depended in part on their age and experience. The daymen included experienced, adult colliers who worked at the coal face, and boys and youths in various stages of learning the craft, for the "off hand" work of loading, moving materials, cutting and setting timber, and hauling tubs from the face to the main transport roads. The numbers of daymen in each stall varied according to the needs of the butties, but there were not many of them: perhaps there was a ratio of two butties to four or five daymen.

The butty's power of employment and dismissal was important, given the nature of the principal markets for Forest coal. A small iron-making and iron-processing industry had grown up in Dean, which, together with mills at Stroud, took about one fifth of output in $1870 . .^{6}$ But most of the coal, perhaps two thirds of it, went away by railway or in the barges of the Severn, to compete in the house-coal trade of Southern and Southwestern England. That, of course, was a seasonal trade, whose peak came in winter. At the beginning of spring, as trade slackened and the prices of the house

4 This account of the colliers' work in Dean is based on H. R. Insole and C. Z. Bunning, "The Forest of Dean Coal Field", in: British Society of Mining Students, Journal, V and VII (1881); and on J. S. Joynes, "Description of semas and some of the methods of working in the Forest of Dean", ibid., XI (1889).

5 The little butties should be distinguished from the "big butties" or "charter masters" of Staffordshire, who worked a whole pit, seam or group of stalls. On the big butties, see $\mathrm{H}$. S. Jevons, The British Coal Trade (Newton Abbott, 1969; first ed. 1915). pp. 455-57.

${ }^{6}$ R. Meade, "The Iron Industries of Gloucestershire, Forest of Dean", in: Mining Journal, 1 April 1876; R. Hunt, Mineral Statistics of the United Kingdom for 1869 [Geological Survey of the United Kingdom] (London, 1870). 
grades fell, the demand of the butties for labour also fell. Customarily, men left the pits and went into the countryside to look for work on the farms, returning to the coal when the weather cooled in the autumn. ${ }^{7}$ Many men had a dual life over the course of the year as colliery daymen and agricultural labourers. The rate at which men were laid off and the rate at which pay altered with shifts in demand, coal prices and contract rates were the choice of the butty.

Within that larger cycle, the butties adjusted to fluctuations in demand at their own pits by offering more or less turns per week to the daymen.

butty men [...] contract to get coal from a stipulated area at so much per ton, and in turn employ labourers. It is this latter class who make so little time when trade is slack; the butty men, naturally enough as masters of the situation, can generally find enough to do while they can send their labourers home. ${ }^{8}$

The daymen seem indeed to have been almost a casual labour-force who suffered or benefited from every shift in the wind of trade. We can imagine that they experienced all the uncertainties and the relationships of dependency with their immediate masters that afflict any casual labourforce.

No wages books or company accounts are available for the Forest of Dean in this period, but a record survives of a number of wages sheets which were submitted to delegate meetings of the district union as evidence in disputes. Those sheets allow some insight into the operation of the butty system. The first set of sheets refers to the two fortnights in March 1874 worked by four companies of men at the collieries of William Brain. Brain had sent the sheets to the delegate meeting in support of his contention that the men concerned were making relatively good money and could afford to take a cut in wages. The delegate board did not contest the validity of the accounts, but instead decided that it could not support the men in resistance to cuts. Unlike the first set of accounts, the second dates from the period immediately following the collapse of the coal markets in the middle of the decade. They were offered to the delegates as proof that "there were exceptional cases in which the butty men were unable to get for themselves any money after paying their underhands". Though exceptional, they do indicate the way in which the fortunes of the butty could vary. The third account was submitted by two buttymen in support of an application for help in taking the master to court in order to recover unpaid moneys. The form and the content of the account were not in question, only whether the money had been paid.

7 See for example, Colliery Guardian, 3 August and 7 September 1867.

8 Ibid., 31 July 1885. 
Table 2. Some wages sheets for Forest of Dean colliers, 1874-75

William Meek's account, fortnight ending 7 March 1874

Paid to Moses Meek 9 days at $3 / 8 d$

f1.13.0

Richard Meek 9 days at 2/6d

f1. 2.6

James Pritchard 9 days at $3 / 4 d$

$\mathfrak{£} 1.10 .0$

40 per cent

£1.14.0

William Meek equal to 9 days at 21/6d

$£ 15.13 .6$

Idem, fortnight ending 21 March 1874

Paid to Moses Meek 101/2 days at 3/8d

Richard Meek $10 \frac{1}{2}$ days at $2 / 6 \mathrm{~d}$

James Pritchard $101 / 2$ days at $3 / 4 d$

40 per cent

William Meek equal to $10 \frac{1}{2}$ days at about $18 /-$

1.18 .6

fl. 6.3

$£ 1.15 .0$

£2. 0.0

f 5.19 .6

£ 9.14 .0

£16. 9.9

Thomas Philips's account, fortnight ending 7 March 1874

Paid to Phillip Nichols 5 days at 5/-

G. Kear 5 days at $5 /-$

£1. 5.0

f1. 5.0

£ 6.19 .9

£ 9.10 .0

£ 6.10 .0

Thomas Phillips equal to 5 days at 16/-

Idem, fortnight ending 21 March 1874

Paid to Phillip Nichols 9 days at 5/-

Thomas Phillips equal to 9 days at about 10/-

Elijah Mathews's account, fortnight ending 7 March 1874

Paid to E. Mathews 9 days at 3/8d

J. Roberts 9 days at $3 / 4 d$

J. Baggs 9 days at $3 / 8 d$

S. Powell 9 days at $3 / 8 d$

Two boys 9 days at $3 / 4 d$

40 per cent

$£ 1.13 .0$

£1.10.0

$£ 1.13 .0$

f1.13.0

£1.10.0

£3. 4.0

£11. 3.0

E 7.4 .9

Elijah Mathews equal to 9 days at 16/-

Idem, fortnight ending 21 March 1874

Paid to E. Mathews 11 days at $3 / 8 d$

f2. 0.4

£24. 1.9

J. Powell 11 days at $3 / 8 d$

£2. 0.4

S. Powell 9 days at $3 / 8 d$

£1.13.0

J. Baggs 9 days at $3 / 4 d$

$£ 1.10 .0$

J. Roberts 9 days at $3 / 4 d$

£1.10.0

40 per cent

f4. 1.0

£14. 4.8

$£ 9.17 .1$

Elijah Mathews equal to 11 days at about 18/-

Joseph Baldwin's account, fortnight ending 7 March 1874

Paid to One man 9 days at $3 / 8 d$

$£ 1.13 .0$

£16. 8.10

Geo. Roberts 9 days at $3 / 4 d$

$£ 1.10 .0$

Two boys 9 days at $3 / 4 d$

$£ 1.10 .0$

40 per cent

£1.17.0

$£ 7.12 .0$

$£ 8.16 .10$

Joseph Baldwin equal to $10 \frac{1}{2}$ days at $16 / 9 d$

Source: Forest of Dean Examiner, 22 May 1874. 
Samuel Saysell and Jude Williams's account, first fortnight of December 1874

Earnings: 6 carts at $10 \mathrm{~d}$

293 carts at $7 \frac{1}{2} \mathrm{~d}$

£0. 5.0

For cleaning ginne

£9. 3.1

ney road

f1. 0.0

10 per cent

Paid to G. Evans 12 days at $5 / 6 \mathrm{~d}$

f1. 0.9

£3. 6.0

£11. 8.10

T. Wright 10 days at $5 /-$

$£ 2.10 .0$

J. Walden 8 days at $5 / 6 \mathrm{~d}$

£2. 4.0

W. Hall 10 days at $5 / 6 d$

£2.15.0

T. Fry 2 days at $5 / 6 \mathrm{~d}$

f0.11.0

H. Thomas 11 days at $2 / 4 \mathrm{~d}$

£1. 5.8

$£ 12.11 .8$

Loss of

f 1.2 .10

Idem, second fortnight of December 1874

Earnings: 15 carts at $10 \mathrm{~d}$

311 carts at $7 \frac{1}{2} \mathrm{~d}$

$£ 0.12 .6$

Drawing 24 supports

f9.14.4

10 per cent

Paid to G. Evans 10 days at $5 / 6 \mathrm{~d}$

£0. 2.0

f1. 0.9

£11. 9.7

T. Wright 11 days at $5 /-$

$£ 2.15 .0$

£2.15.0

J. Walden 4 days at $5 / 6 d$

£1. 2.0

J. Saysell 4 days at $5 / 6 \mathrm{~d}$

£1. 2.0

T. Fry $21 / 2$ days at $5 / 6 d$

$£ 0.13 .9$

W. Hall 9 days at $5 / 6 \mathrm{~d}$

£0. 9.6

H. Thomas 10 days at $2 / 4 \mathrm{~d}$

£1. 3.4

f12. 0.7

Loss of

£ 0.11 .0

"They had as well 5/- a yard on the cross headings which they let to Saysell's brother, excepting a few yards, and having relet the heading work at 4/- raised their net earnings by $£ 2$, which left them $6 / 2$ to divide between them." In the first fortnight Saysell worked $61 / 2$ days and Williams 11 . In the second, Saysell worked 8 and Williams 7 days.

Source: Forester, 7 January 1875; Forest of Dean Examiner, 8 January.

Shellah Russell and Joseph Burris's account, January-May 1874

Earnings:

Preparing the Lowery Brow at Waterloo Colliery

$£ 16.10 .0$

Sinking pit from the Lowery seam to the Starkey seam

f83. 0.6

Drove 16 yards and 2 feet of heading in the Regulator Colliery at 15/-

per yard

Worked Regulator Colliery Engine 19 days at $6 /-$

$£ 12.10 .0$

£ 5.14 .0

$£ 117.14 .6$

Paid to C. Coleman 101/2 days at $6 /$

£3. 3.0

E. Davis $11 \frac{1 / 2}{2}$ days at $5 /-$

$\mathfrak{£ 2 . 1 7 . 0}$

W. Morgan $91 / 2$ days at $6 /-$

$£ 2.17 .0$

J. Hall 4 days at $6 /-$

£1. 4.0

$\frac{£ 10.1 .0}{£ 107.13 .6}$

Assuming that there were ten fortnights in the period, Russell and Burris made an average of $£ 57 / 8 \mathrm{~d}$ each per week.

Source: Forest of Dean Examiner, 5 June 1874. 
Several features of the accounts are noteworthy. There is the variation in the earnings of the butties. Brain's butties earned as little as 10/-per day on average and as much as $21 / 6 \mathrm{~d}$. Samuel Saysell and Jude Williams earned, on the other hand, in the last month of 1874, less than they had to pay out to their daymen. The rate for the daymen was more stable, though in most cases their earnings were well below those of the buttymen. The percentage added to the daymen's rates, the result of union agitation in the favourable conditions of the coal boom, varied as the depression deepened and the union lost its bargaining power. We notice also that the rate paid to different men was not uniform and that the number of days that different men in the same work gang put in varied. This is most marked in the second set of accounts for the period of slack work in the winter of 1874 . While Thomas Wright worked eleven days for Saysell and Williams in the second fortnight of December 1874, John Saysell worked only four and Thomas Fry two and one half.

There seems to be a clear difference between the earning potential of the butty and the dayman. Perhaps there were exceptional cases in which the butty had little or no return, but when the bargain he had made with the master was a fair one, when demand was up and prices were high, the butty was probably able to make a good deal more than the dayman. Unless that were so on average, it is difficult to know how the system could have continued. Certainly, in March 1874, the four men that we know about earned between $10 /$ - and $21 / 6 \mathrm{~d}$ per day, on average, while the best of the experienced men employed by them made only $3 / 8 \mathrm{~d}$ plus forty per cent. Perhaps the difference in normal times was not so spectacular, but the peak demand for house coal in winter and the impact of falling demand in the spring, which fell first on the regularity of the dayman's work, made a permanent difference between the economic experience of dayman and butty.

These accounts also suggest something of the variety of the collier's work and of the ways in which he made his money: the butty had to be something of an entrepreneur within the pit. While the principal source of his earnings was the cutting of coal to be sent out of the pit for sale, there were other jobs to be done. The pit had to be developed, that is, roads had to be driven out through the bulk of the coal so that working places might be turned away, and when the pit worked more than one seam, or where a seam had been broken or displaced by a geological fault, smaller pits or drifts had to be made within the mine. If pillars had been extracted, the space left, the goaf, had to be packed with stone or timber supports; and perhaps stone or timber left in earlier work had to be shifted so as to direct roof pressures away from roadways or working places. 
At some pits, as we have noted, men were employed on day wages to do this sort of work (the master's daymen). In others the colliers did it along with their other work. In that case the butty had to bargain for the work and the rate to be paid for it. Saysell and Williams made part of their money for cleaning the road and drawing roof supports. Russell and Burris made most of their pay over a five-month period from this sort of "off hand" work. They made ready a section of seam to be worked by other men, sank a pit from one seam to another, drove headings and worked the pumps at another pit owned by the same master. For this they made an average of $£ 5$ $7 / 8 \mathrm{~d}$ per week in that period. The highest amount that they paid out to a dayman in that time was $£ 33 /$ - to Charles Collins for $10 \frac{1}{2}$ turns, or a fortnight's work. Again we note the differing times worked by the daymen: James Hall had only four turns from them. We may note also in the second set of accounts that Saysell and Williams had made a bargain for heading or road work at $4 /-$ a yard. They sub-let the cross headings to Saysell's brother and the headings to other men. This was not an act of charity to a brother or to a brother collier, but a bargain which realised a profit of $£ 2$ in the month for the buttymen.

Here, then, is the context of colliers' unionism in Dean Forest. Most of the coal came from a relatively small number of large pits whose cycles of work varied with the effect of the seasons on the house-coal trade. Whitin those pits, work was organised around the butty contractor, a small-scale employer and entrepreneur in his own right. His profit depended on the daymen who comprised a casual day labour-force, dependent on the discretion of the butty for their pay and work. How did this system affect union in Dean?

There were no colliers' unions in Dean before 1871. There had been some stirrings of unrest in the early 'sixties and some initial - unsuccessful steps had been taken towards the formation of a union. ${ }^{9}$ But it was not until after the formation of the Amalgamated Association of Miners in 1869, with its central strike fund and the promise of support against the employers which it offered to its member districts, and after the beginnings of the economic boom of the early 'seventies had given them a strong bargaining position, that the men of Dean were able to undertake an open union. ${ }^{10}$

9 Miner and Workman's Advocate, 25 June 1864.

10 Perhaps there had been some sort of covert activity before this. In 1870 , correspondence appeared in the local newspaper signed by an anonymous "Miners' Committee". Forester, 30 December 1870. 
In July 1871 a strike broke out among the 800 men and boys employed at the Trafalgar colliery. ${ }^{11}$ That was followed about two months later by another strike at the Parkend Coal Company, which employed about 600 men and boys. ${ }^{12}$ Both Trafalgar and Parkend were large house-coal pits, and both strikes were begun and led by buttymen. Both strikes were about buttymen's problems: contract hewing rates, the weighing of coal at pit bank, and the appointment of checkweighmen to see that the weights credited to the miners were fairly taken. Both strikes, moreover, against a background of rising coal prices and strong demand for labour, ended in victory for the colliers. More importantly, in the course of these disputes the buttymen formed a "union club", which quickly became a branch of the Amalgamated Association of Miners. ${ }^{13}$

Under its shelter, and in the favourable conditions of the boom, the union won a number of important concessions from the masters. In summary: by 1873 contract rates had been pushed up by forty per cent over those of 1870; weighing machines had been generally installed on pit banks; and winding hours had been reduced from ten to eight at the large pits. This sort of success kept membership at relatively high levels. At its peak in 1874 the branch had 4,500 members, or about eighty per cent of the total number of colliers in the district.

Apart from the, predictable, opposition of the masters, the first problem for the organisers of the union was disunity among the butties. William Morgan, a butty, had raised the question of divisions among the men at a meeting in Cinderford Town Hall in October 1871. He complained of the ways in which the masters might set the men against one another.

I have seen a good many "places" in my time where the men after working ten or eleven days could not obtain their wages. At these times men have gone to their bailiffs and begged for a little more money, and at times "it has been given". At other times the bailiff would say "go to the master". They had gone and were told this, "Your place dont pay me to work it you must shut it up, if you cannot make it pay for that money, let it stand." Hoping it may turn out better men have toiled and toiled [...] and we have gone labouring and toiling on month after month hoping that the place would turn out better, and then at last after long struggling have been obliged to give up the place altogether. After a bit another man has been given money "just to try it", and in that way it was not unusual for these men to reap the

11 Ibid., 7 July 1871.

12 Ibid., 8 and 15 September.

13 On the Dean branch of the AAM and its relationship with the national union, see $\mathrm{Ch}$. Fisher and J. Smethurst, "War on the Law Supply and Demand": The Amalgamated Association of Miners and the Forest of Dean Colliers, 1869-1875", in: Independent Collier, op. cit. 
fruits of other mens' labours. What is to prevent this being done? There is no other way open to us than to have a union and stick together. ${ }^{14}$

If a miner asked for a rise of rates in a difficult workplace, Morgan said, the employer would "say 'so and so will do there very well', making believe they have better men and more experienced colliers". Some men, the "decoy birds", allowed themselves to be used in that way and thus they all fell to "wrangling and fighting".

There was also the problem of the division between dayman and butty. The strikes from which the union had grown were buttymen's strikes, but at a time when the strike was the butty's principal bargaining weapon - there were no arbitration boards or other such institutions to govern the behaviour of master and man - the daymen could not be ignored. Some of them, more or less experienced, might welcome the chance to play the blackleg and take up stalls of their own. It was necessary therefore that the union should take in both classes of men.

Then I mean to say stick to one another. I will venture to tell the coal and mine cutters of the Forest of Dean that it is as much your duty to stick to the daymen as in your case, if you are dissatisfied with the price paid for cutting the coal, to expect the men to stick to you (Loud Applause). When the buttymen recently gave notice to the masters they wished all the daymen to turn out along, and in some cases they have done so. Now if they stick to you, my advice is to stick to them. If we are to have a union let us have it (Applause). The fact is, we have been frightened, that if anything was said Tom would take Jim's place, and Jim would take somebody else's place. In this way we have been frightened, and have thus given our masters an advantage over us. ${ }^{15}$

For the union, a resolution at its first meeting, that wage advances should be passed on in proportion to all workers, was as important as the capitulation of the Parkend masters.

But, however tactically important that was, this union was no promoter of an egalitarian uniformity among men, so far, at least, as its own membership was concerned. We may see this in the principles which underpinned the union's wage bargaining. Firstly, there was a recognition that the butties undertook risk. That made their earnings unpredictable and a matter, to some extent, of luck rather than skill. The union accepted that condition of the butty's work. Thus, when the district delegate board pondered the question "What is a fair day's wage", in September 1873, it decided that no standard could be set for the butty. The chairman of the meeting summed up the argument:

14 Forester, 6 October 1871.

15 Ibid. 
the butties or contractors [...] made the best contracts they could with the managers or bailiffs [. . ]. Now there was often great uncertainty in carrying out the work; because no man on being allotted a stall could say what difficulties might be met with: colliery work was not like some other work which a man could see what he had to do. [.. .] He did not, himself, see how it was possible for their district at present to lay down any rule as to what was or should be a standard wage. ${ }^{16}$

The butty - not the union - made his contract and then did with it what he could.

More than that, the union accepted the fact that the butties, as entrepreneurs, were competitors in bidding for work. In October 1874, Mr Jones of Whitecroft appeared before the delegate board to complain that another member had taken his work. Jones and another man had tendered for a job at one pound per yard, but had lost the work to Mr Tyler, who had offered to do it for fourteen shillings. This, Mr Jones thought, was contrary to the spirit of unionism, but the delegate board disagreed.

The Chairman reminded Mr Jones that this work was to be estimated for, and he had the same opportunity as others to put in a tender for it. It was not a question as to the men but who was the lowest, at the same time it was scarcely creditable to Tyler who had another job, to estimate in this case. A delegate stated that [...] he (the Speaker) would have as much right to give in a price of $12 \mathrm{~s}$ as Tyler did at $14 \mathrm{~s}$, and Jones at $20 \mathrm{~s}$. It was given to the lowest man, and was now nearly finished, and doubtless there would be a chance for others to estimate on any further work. He could not see how any censure could be passed on Tyler. ${ }^{17}$

Some mild disapproval for Tyler's greediness, perhaps, but none for the system of competitive contracting under which they all worked.

What the union did wish to insist upon was that butties should be paid their fair "market value". ${ }^{18}$ What was their market value and how was it to be known? Market value was the wage dictated by the labour market from time to time and it was to be known by watching the price of coal. As a matter of fact, the miners' agent argued, "the prices of coal and iron are the only index to which either masters or men can refer for guidance as to the condition of the labour market and they form an infallible guide". Workmen, therefore, were entitled to rises in their wages in proportion to advances in the price of coal, "and what is more, if they are wise they will insist on having it". ${ }^{19}$ The butty and the master made their bargain given

16 Forest of Dean Examiner, 27 September 1873.

17 Ibid., 6 November 1874.

18 Forester, 2 September 1871.

19 Ibid., 20 September 1870. 
the price of coal in the market place at a particular time. If the price rose, the amount of the advance should be passed back to master and butty in the proportions already established by the ratio of contract tonnage rates to coal prices. In other words, the logic and mentality of the sliding scale governed the share-out between master and butty long before the disasters and defeats of the second half of the decade and before the institution of formal sliding-scale agreements.

Now, market value was not understood to be the same rate for all men. The distinction between the skilled and the unskilled was reflected in what it was thought their market values were.

The Agent said he had had a conversation with the manager at Lightmoor, who had told him that if there were any men working at the colliery not receiving marketable value for their labour - he was referring to the men who could do a day's work either in putting timber or beginning and finishing their work in a proper manner - they should be paid it. ${ }^{20}$

The manager would not increase the pay of men "who could only fill a cart". This was not at all unacceptable to the delegates, whose debates were often punctuated by the disclaimer that it was only the skilled men to whom the speaker referred.

The delegate board had decided that the daymen should probably have, so long as they were skilled, experienced colliers, a standard wage of six shillings a day. This discussion provoked a series of letters to the Forest of Dean Examiner, the "official organ" of the union. Those letters give us some insight into the nature of the butty system and the assumptions of butty unionism. Offering as they do a view of the colliers which has not found a place in the received histories, these letters are worth setting out at some length. A butty, one Henry Jones, wrote to say that

I find that there is a spirit of restlessness and disquietude in the breasts of some men about the question of wages, and that there should be an average throughout the Forest district. I wonder where we shall find either the man or men that can bring about such a state of things. [... .] if an experienced man, either by mental or physical powers, can so manage his stall as to send more coal than the other, shall both have the same wages?

Secondly as regards day men's wages, here they are - some from the smith's shop, others from the shoemaker's bench, others from the plough tail, and so on. First they begin to have them to fill, then to pick up, and some of them both; and others are very neglectful, where others are more provident. Shall all these men have the same wages? How monstrous to talk of such a thing, when I, for one, know that some men are worth 1s per day more than others. Thirdly, as regards timberers in the road, these men are

20 Forest of Dean Examiner, 30 August 1873. 
obliged to be kept on all coal works in the district, but these vary, both in steadyness and experience. Some of them will stay away from their work while others will be found at their work, and one man can make a pair of timber, while the other is turning the timber about. Again, one man will see which way to put the setting up, and do it, while another will be tapping this and that, and sacking up his trousers. Shall these have the same wages? If the timberer is a steady and good workman and his wages will not do for him, let him ask for a stall, and tell his master his reasons, and not think to bring wages on an average. ${ }^{21}$

For Jones, all men were not equal. They varied in their providence, work habits and mental and physical powers and should be paid accordingly.

The same issue of the Examiner printed a defence of the dayman's honour, a truculent letter which dared to suggest that the dayman was every bit as skilled as the butty.

I know that the dayman is thought very little of by some men. But we must not condemn all for some. However, I would advise them not to take any notice of that, but ask the master to give him the chance of a head or job work and not only one but all men that could do such work as timbering, and then the master would soon see which class of men was worth the most, head men or road men, for if all that class of men would do that it would be better than meeting and talking things over, for I believe that there is not one in ten, take the Forest through, that work in the heads, that can do the work as a timber man, although they think that because they are buttymen they are all. ${ }^{22}$

Another correspondent did not go so far as to suggest that daymen and butties were of the same calibre, but he was careful to distinguish the experienced coal cutters from the clod hoppers recently come from the plough tail. His principal grievance was his vulnerability to sharp practice on the part of the butty.

Many believe that an average rate of wage throughout the district should be insisted upon by union men. Mind you, sir, I do not mean that Mr Henry Jones's "clod-hoppers" or "Hodges" from the plough tail should receive as high wages as the experienced coal cutter. On the contrary, taking - if I may be permitted - the Rocky men in Lightmoor pits. I object to the system of buttymen there making a distinction between practical hands of from $6 \mathrm{~d}$ to 1s per day. I am one of those who believe that the time has come when the ordinary collier should speak plainly out, objecting to the present unsatisfactory method of paying the daymen.

I venture to say that every day collier able to do a fair eight hours work ought to have the same uniform standard wages together with his forty per

21 Ibid., 25 October.

22 Ibid. 
cent. Having in general terms explained the grievance of our daymen - or at least many of them - I would affirm that in the Rocky vein, where I am a day collier, there are some butties who out of every five per cent pay their men at a reduced rate, instead of what is fair, just and honourable. The fact being they keep to their own check what is due to others.

Again, some of the butties object to pay the coal money, others pay none at all, and such is the state of things prevailing at the colliery named.

I would, in conclusion ask, is it right these men should be allowed to continue a system attended with so much injustice? I should like, sir, to see the day arrive when the butty men - if we are to have butty men - and daymen combine in that which is right, instead of the former trying to rob the latter. ${ }^{23}$

He might have added that the butties, or some or them at any rate, continued to own small shops and beerhouses, and to pay the men in truck. The old custom of sharing out the pay at the beerhouses and insisting that the men in the company contribute to a drinking fund for the night also continued, to the disgust of the union officers. ${ }^{24}$

But perhaps there was something to be said for the butties. After all, they were entrepreneurs; they took risks. When the butty committed himself to open out a stall, he could not predict how well the work would go and he might indeed make a loss.

I am a day collier, and have worked for different buttymen [...] and I am proud to work for a butty [...]. After a butty has been working month after month, and no money to carry home to his wife, then the wife would say, "What, no money this time?" "No: I have had to borrow the money to pay the chaps." Well, the wife goes to the shopkeeper. Mr "so-and-so" I want you to trust me with another fortnight's things, my husband has brought me home no money again. The reply - oh, I cant let you go on any further, you must transfer your pig over to me for things you have had already. I know this to be the fact. I will not say this is the case with all in opening their stalls: It has been with more than one or two I have worked for. ${ }^{25}$

To this "A Forester" responded not at all unreasonably:

With regard to the buttyman's loss from month to month [ . . . I will ask why are these old buttymen, when they finish out a stall, so anxious to get another? We daymen have nothing to do with the contract between the buttymen and the masters, that is purely their own affair. I for one, however, protest against having my wages deducted in the way and manner that some buttymen treat their underhands. ${ }^{26}$

23 Ibid, 14 November.

${ }^{24}$ Report of the Royal Commission on Truck [Parliamentary Papers, 1871, XXXVI], pp. xci-xcii.

25 Forest of Dean Examiner, 21 November 1873.

26 Ibid., 18 November. 
For the butties, the case was a simple one: mining was a skill which some men possessed to a greater degree than others and differences among men were a matter of personal worth and quality.

I am sorry to say that there are a great number of men at Lightmoor who are not capable of being in a stall without the butty. I might say without hesitation, that a great many more lives would be sacrificed than at the present time, because there are a great number of persons who are not competent miners, and do not possess those capabilities which are requisite to enable them to carry on a stall either safely or beneficially. $[\ldots]$ they ought to be thankful to think of the butty taking them from the plough tail, and for the instruction given them to try and bring them as financial as good as themselves. The butty does not scandalise any incompetent person, but is doing much good for him daily in trying to make them if possible, practical miners. ${ }^{27}$

Another wrote to say that the debate should be discontinued because it was divisive: that such discord among the men would surely kill the union tree. In a letter cast almost in the form of a sermon he exhorted them to charity towards one another and urged them to keep in sight the need for brotherhood. For all that he was not able to resist a word or two on behalf of the butties and against the sort of dayman.

I have had to contend with this thirty years, if they are taught one rule just to cut a yard of paling, or get a lump of coal with an iron bar. That they have gone so far, and they know all better than their employers, the butty as they call him. I have had many of that sort that have thought they had been getting $3 \mathrm{~d}$ or $4 \mathrm{~d}$ a day for me, and I mean to assert that 19 out of 20 such never do enough work to pay their own expenses, and hundreds can testify to the truth of my assertions. But on the other hand I have known some butty colliers very austere and exact, so much that they have been too keen to be honest [ . . . . If you are an accomplished man as a collier, if you cannot prevail on your present employers to entrust you with a place, you shall come with me, and whether you are old or young, if you do the same work as myself, you shall fully share the profits. I have refused a great many of these public house slashers and have put them in stalls by asking the bailiff for them, and they have cut and mangled their work place to such an extent that in less than a fortnight they have grown to such an enormous size that they were not able to get their body under the roof, and have come back to me acknowledging that they have not got is $6 \mathrm{~d}$ per day. ${ }^{28}$

Needless to say, the union did not introduce a standard wage for the daymen. The butty, after all, was an employer whose profits depended on the efforts of those he employed. If the daymen contributed unevenly to

27 Ibid.

28 Ibid., 2 January 1874. 
profits, then they should be paid unevenly. There was no question of holding the daymen back: if they thought they could manage a stall, become butties themselves, then by all means let them do it. If they failed, only they would lose by it. But the butty's freedom to discriminate among men as he chose should not be limited. This union gave sanction to and perpetuated the gradations and distinctions of the labour process.

Looking up the scale of the social order, the union was not so ready to insist upon distinctions. The buttyman was perhaps not the equal of his master in point of social grace and education, but nor was he to be given less than his due. Labour and capital - labour considered as the skilled contractor - depended on each other, were necessary to each other's prosperity and should deal with each other accordingly. William Owen, editor of the Forest of Dean Examiner, argued that working men "are not likely to kill the goose that lays the golden eggs by impoverishing or driving out of the country those most useful allies of theirs, the capitalists who provide the resources necessary for carrying out large industrial operations". ${ }^{29}$ For William Brown, vice president of the AAM, capital and labour were like the blades of scissors, "unless there be the two blades there can be no cutting. (Cheers) Capital cannot succeed without labour, neither can labour succeed without capital." 30 So too for Timothy Mountjoy. In August 1873 he went to the village of Clearwell in the Forest to speak at the opening of a new lodge. He said to the assembled men:

I hope that the interests of employer and the employed will go hand in hand together and your lodge will bear fruit. Let Truth and justice, and not might rule, and strikes and lockouts cease to be. Combination is power, and I hope this gathering will be good and trade and commerce still improve on this side of the district. I also hope that moderation and equity will guide you. We desire for our society the strength which intelligence and true unity can give; what we want is fair remuneration for masters and men - the united interests of both considered. ${ }^{31}$

The master provided the capital structure within which the butty took his risks and strove to make a profit. The master depended on the initiative of the butty. How could their interests be incompatible?

But perhaps this luxurious despising of hodges and impertinent assumption of a functional equality with capital was the product of the economic boom? The cohesion of the colliers surely was greatest when times were hard? If the little-butty system is to be thought to have made a

31 Ibid., 30 August 1873. 
difference worth noticing, it must be shown to have influenced union behaviour and relations with the master in times of adversity.

\section{III}

Adversity came towards the end of 1874 , as the coal markets began to fall and the masters in all the coal districts began to insist on wage reductions. In the Forest a wage reduction in November 1874 led to strike which lasted until February 1875 . The union was thoroughly beaten and its membership began to fall away, first to 1,000 and then to 400 in $1877 . .^{32}$ In 1877 the district council, unable to prevent further wage reductions, discharged the agent and disbanded itself. ${ }^{33}$ District organisation remained defunct from then until 1882. A new district union formed in $1882 \mathrm{had}$ some brief initial success in its dealings with the masters, but within a few years had also become ineffective. In this period of weakness and instability, as in the preceding period of strength, the behaviour of the union was directed by the fact that it was first and foremost a buttymen's union.

During the strike of 1874-75, as in the strikes at Trafalgar and Parkend pits in 1871 , the union concerned itself narrowly with the wage problems of the butty. The union directed its bargaining, in accordance with its previous wages policy, at establishing the precise numerical dimensions of the relationship between the market price of the product and the market value of the butty. To that end, the union demanded the institution of a formal sliding scale. Once a basis could be fixed for the scale, the Examiner prophesied, "the great contention of wages need no longer be a bone of contention between master and man. And that evil removed there is very little left to quarrel upon." 34 The "basis" was the main obstacle to agreement between the Forest masters and their men. There was no disagreement about the assumption that coal prices and tonnage rates should move together. The colliers wanted the formal expression of a relationship between prices and rates which they had already accepted: that for every rise or fall in the price of coal of one shilling, wages should move by five per cent. ${ }^{35}$ The sudden fall in prices in 1874 and 1875, however, had created two difficulties. Firstly, there was disagreement about the point at which falling prices should provoke a cut in rates. The colliers believed that their rates had not increased during the boom in proportion to coal prices. There should not, therefore, they argued, be wage reductions until prices had

32 Forester, 16 May 1878.

33 Ibid.

34 Forest of Dean Examiner, 21 August 1874.

35 Ibid., 11 December. 
fallen to the same percentage margin over those of 1871 as rates were over those of $1871 .{ }^{36}$ Secondly, it was difficult to tell when rates and prices had fallen into their pre-boom relationship, because no one seemed able or willing to say whether coal sold at fourteen or sixteen shillings the ton in the winter of $1874 .^{37}$ In other words, this strike was about an apparently unfair advantage which the masters had obtained over the butties in the confused competitive situation which came with the breaking of the boom.

The true conclusion to the strike came, not when the men were forced back to work in February 1875, but in July, after another two cuts in the rates. ${ }^{38}$ At that point the masters met the lodge representatives at the village of Littledean and agreed to the establishment of a formal sliding scale for the Forest. The "basis" was taken to be twelve shillings per ton at the pit mouth for best screened block and, for tonnage rates, fifteen per cent over the rates of 1871 . From that base, rates were to move five per cent for every movement of one shilling in prices. ${ }^{39}$ There was nothing extraordinary about this, of course. There were sliding scales in other coalfields and in other industries. ${ }^{40}$ What is of interest here is that the scale in Dean, by linking rates and prices, effected an agreement only between the masters and the buttymen. There was no provision for the daymen, who were left by default to the kindness of the buttymen. After all, if rates were to be settled by a formal mechanism, wage strikes would not be necessary, the daymen would pose no threat, and there would be no point in organising them or providing for them.

The failure of district organisation after the strike further re-inforced this concentration on the problems of the butty. The masters were responsible for that. During the strike they had refused to negotiate with Timothy Mountjoy or the district officers, who, the masters said, were inflammatory agitators, to be blamed for the fact that there was a strike at all. ${ }^{41}$ From that point each of the masters would meet his own men, but not the officers or the agent. Where collective decisions were necessary - as at Littledean individual pit deputations might congregate but, again, were not to speak through an agent. Thus, as the strength of the district union ebbed, the separate lodges became relatively more important.

Now, as that happened, the checkweighmen also assumed a greater importance. Authority to appoint their own checkweighmen had come to

36 Ibid., 13 November.

37 Ibid., 20 November.

38 Ibid,, 9 July 1875.

39 Ibid., 30 July.

40 J. H. Porter, "Wage Determination by selling price sliding scales, 1870-1914", in: Manchester School of Economic and Social Studies, XXXIX (1971).

41 Forest of Dean Examiner, 11 December 1874; 15 February 1877. 
the miners from the Mines Act of 1872 . Elected by the butties and paid by them, the checkweighman was perhaps the only person in the pit who was capable of maintaining independent action, of surviving moments of vindictiveness on the part of the master. The checkweighman, therefore, became the focus of lodge organisation, keeping the books, calling and chairing meetings and leading deputations. ${ }^{42}$ So far as union persisted, it did so in the hands of the elected, paid servants of the butties, on whose goodwill they depended for their living. ${ }^{43}$ When optimism returned in 1882, it was the checkweighmen who brought the lodges together in a new district organisation, whose first president was a checkweighman, John Ennis. ${ }^{44}$

As agent, the new district council employed Edward Allen Rymer. His recent history might have encouraged the council to have imagined that his notions of unionism would coincide fairly well with its own. In Yorkshire he had been an advocate of the sliding scale and a prophet of conciliation and arbitration. ${ }^{45}$ His initial approach to the Forest masters was accordingly moderate and respectful in tone. The colliers did not wish to enter into strikes or lock-outs, he informed them, but would appeal to their "sense of honour and Christian philanthropy" in asking for a wage advance. ${ }^{46}$ Since the masters had fallen into price competition amongst themselves and had in practice abandoned the Littledean agreement in 1879 , Rymer also appealed to them to establish a board of conciliation and a sliding scale. ${ }^{47}$ Within two months of his arrival, however, he had fallen into dispute with the weighmen. Rymer saw himself as the embodiment of the will of the colliers. He expected the weighmen to act as servants of the district union and to accept the policy that he formulated for it, interpreting opposition to the policy as opposition to unionism. ${ }^{48}$ Though protesting that they were good union men, the weighmen asserted that they had a first duty to the butties and were reluctant to subordinate themselves to Rymer, who denounced them as tools of the masters and moved a resolution at a mass meeting, apparently unsuccessfully, that the weighmen all undergo re-election. ${ }^{49} \mathrm{He}$ did succeed in having all the checkweighmen excluded

42 Dean Forest Mercury, 15 December 1882.

43 Ibid., 25 August.

44 Ibid., 8 December.

45 Barnsley Chronicle, 5 March 1881. On Rymer see Ch. Fisher and P. Spaven, "Edward Rymer and 'The Moral Workman"', in: Independent Collier.

46 Dean Forest Mercury, 1 December 1882.

47 Forester, 28 October 1882.

48 Dean Forest Mercury, 15 December 1882; 14 December 1884.

49 Ibid., 8 and 15 December 1882. 
from membership of the district council. ${ }^{50}$

This was in part a quarrel about relative authority within the union, but it was also a more fundamental dispute about the purposes of unionism. Rymer's cautious, moderate, market-conscious unionism had only come to him after the defeats and disasters which followed the collapse of the boom in 1874. Before that he had been an exponent of opinions which were basically at odds with those of the butties and their weighmen. In his earlier career he had not subscribed to any notion of the identity of interest of capital and labour whose measure was to be found in the fixed ratio of coal prices to tonnage rates. "Whatever be the price of coal or iron, or whatever be the state of trade in the money market, we must have our position made secure and our labour protected from the wolves and vultures of a mean, selfish and brutal generation." 51 Labour was the creator of value and that, not some mechanical "law" of supply and demand, should determine labour's reward. "We create annually over $£ 12,000,000,000 "$ ", he wrote, "We only get a third of the money in wages. We shall demand it all as our own property and hurl your dirty law from us with a philosophical disgust that has never penetrated your numskulls." 52 Arbitration was "but another means of concession to capital, for it allows them to use their organised knowledge in commercial matters against our ignorance." 53 He was pugnacious and aggressive, cast in the mould of "old unionism" and bred in the ways of mass radical agitation, favouring the rhetoric of the Apocalypse and the challenge to oppression and tyranny broadcast to thousands massed on a moor or in a city square, rather than the prudent negotiations of the union official.

To the disgust of the weighmen, this older strain in Rymer came out again once he had established himself in Dean through the winning of a wage advance from the masters. That success had given Rymer great popularity.$^{54}$ Membership of the union jumped from 1,000 shortly after its foundation, to 3,000 in December $1882 .{ }^{55}$ Since that represented three quarters of the colliers in Dean, it is clear that Rymer was not directing his attention exclusively to the butties, but was making a wider, populist appeal to all the workmen in the mines. ${ }^{56}$ Here was a champion for the "ordinary" miner, one who disregarded petty hierarchies and was prepared to fight the weighmen. In appreciation of his services the Drybrook lodge

50 Ibid., 15 June 1883.

51 Miner's Advocate and Record, 18 October 1873.

52 Ibid., 26 July.

53 Ibid., 26 September 1874.

54 Dean Forest Mercury, 16 March 1883.

${ }^{55}$ Forester, 21 October and 2 December 1882.

56 R. Hunt, Mineral Statistics of the United Kingdom for 1874 (London, 1875). 
presented him early in 1883 with a "silver, keyless, chronometer watch with a gold chain". ${ }^{57}$

At this point the masters become important. They had contributed to the downfall of Timothy Mountjoy by ignoring him and the district council and dealing only with the separate lodges. They now proceeded to isolate Rymer in exactly the same way. Though conceding a wage advance, they had refused to establish a board of conciliation. Rymer's reported statements about what the miners would demand, the masters said, made the idea of a conciliation board farcical. ${ }^{58}$ Then, at the beginning of March 1883 , as the spring slackening of the trade began, they took away the wage advance, announced that they would not talk to Rymer or the district officers and locked their men out. ${ }^{59}$

It was not the intention of the masters simply to crush the union. They wanted rather to direct the form that union took. While Rymer raged against them at a mass meeting, the masters met a Staffordshire miners' agent, William Brown, a moderate, "responsible" advocate of conciliation, arbitration and the sliding scale. ${ }^{60}$ Brown obtained from them an agreement that half the proposed reduction should take effect immediately and the other half should go to the consideration of an arbitration board. Rymer denounced these terms and led a large proportion of the men into a strike. ${ }^{61}$ After five weeks, however, the money ran out as it had in 1875, and the men had to go back to work. While Rymer waited in an outside room, the pit delegates met the masters and agreed to resume work on the terms which had been offered to Brown. ${ }^{62}$ Thus the masters had not only won the strike, but had destroyed Rymer's authority.

The masters consolidated their advantage when the board met to arbitrate on the five per cent which was still at issue. Again the district council and Rymer were excluded from the negotiations. Enoch Edwards from North Staffordshire, and William Chappell, of Yorkshire, both men of exemplary moderation, acted as arbitrators for the colliers. ${ }^{63}$ Having agreed to split the five per cent, the arbitrators then agreed on two further points. Firstly, there was to be a sliding scale of the sort which had been arranged in 1875. Secondly, the sliding scale was to run to spring 1884 , without alteration, at which time it was to be re-negotiated by the same

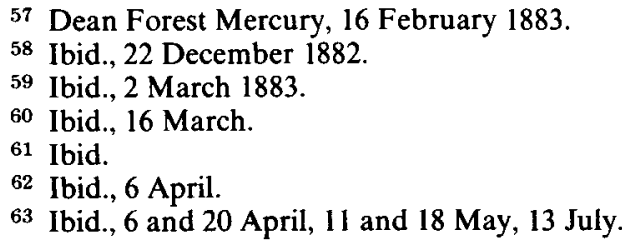


arbitrators. For the central purpose of wage bargaining for the butties, the district union and the agent were now redundant. The re-signing of the agreement in 1885 and 1886 effectively broke the district union. ${ }^{64}$ The scale, like its predecessor, satisfied the needs of the butties and ignored the daymen: both classes then had little to gain from the union, whose numbers fell away rapidly. With great astuteness and a clear understanding of the divisions within their workforces, the masters had countered the threat of Rymer's populist and dangerous agitation, by accommodating the buttymen.

When the union had faded to almost nothing, at the end of 1885 , the weighmen took the opportunity of re-asserting their authority. Each of the pit lodges sent representatives to a meeting called for the purpose of reorganising the district union. ${ }^{65}$ They did not invite Rymer to attend. Rymer accepted the fait accompli, apologised for whatever offence he had given and attempted to carry on as agent. Within six months, however, there were not sufficient funds in the union to pay his wage. The council, therefore, tendered him a reference and, led by the weighmen, set about finding a replacement for him. ${ }^{66}$

It was indicative of the opinion the weighmen and their employers, the butties, had of Rymer that they turned first to William Chappell, advocate of the sliding scale, rather than to someone who might have shared Rymer's fundamental hostility to the employers. ${ }^{67}$ As one of the weighmen had put it,

I do not believe in men that call themselves Union men, who will call everyone who do not see things in just the same light, all sorts of bad names - calling them rotten, and traitorous, and black ball them in every way. I cannot see a fraction of unionism in that; it seems to me more like tyranny and selfishness. Then there are some men who call themselves union men, and they will act any artful dodge to cheat their master, and impose on him in any way they can, even if it were calculated to ruin him. I should not like to daub my hands, tongue or pen with such unionism as that. ${ }^{68}$

When Chappell showed no interest in the job it went to G. H. Rowlinson, who had been president of the AAM's South Staffordshire branch. His first meeting was not for the purpose of denouncing the masters as tyrants and robbers of the value which labour had created or to demand a wage increase. It was a tea meeting, presided over by the Reverend W. Thomas,

64 Ibid., 25 September 1885; 14 May 1886.

65 Ibid., 11 December 1885.

${ }^{66}$ Ibid., 8 January, 28 May, 18 June 1886.

67 Ibid., 16 July.

68 Ibid., 25 May 1883. 
at which Rowlinson expounded his belief that the interests of masters and men were identical. ${ }^{69}$

Our understanding of colliers' unionism, at least in the Forest of Dean, is modified if conventional assumptions about the traditional social cohesion of the colliers are abandoned and the divisions of the labour process are taken into account. The union is seen not to have been concerned in an even-handed way with the problems of all colliery workers. It was the buttymen who started the union in the first place. Their view of pit work governed the behaviour of the union, particularly in the key area of wage bargaining. The butty wanted a fair share of the fluctuating price of coal, but had no ambition to set a minimum rate or standard for his labour: as a small working master he accepted the fact of risk and its influence on his profits. Given a formal sliding scale which would distribute the price of coal equitably between master and butty, there was no reason for them to quarrel. The dayman was, in the union as in the working place, subordinate to the butty. The union made no attempt to abolish the dayman's condition of dependency. For their part, the masters chose to deal with the buttymen through the nexus of the sliding scale and to defend that special relationship against the threat of Rymer. The weighmen, the servants of the butties, were important as mediators of that relationship.

69 Ibid., 24 December 1886. 